\title{
The Coralation Between Sanitation Facilities and Personal Hygiene with the Cases of Diarrhea in Breastfeeding Toddlers in Sinabung Post-Eruption Settlements, Berastagi District, Karo Regency
}

DOI: https://doi.org/10.47175/rissj.v2i3.271

\section{| Irwansyah Lubis ${ }^{1, *} \mid$ Sri Malem Indirawati ${ }^{2}$ | Irnawati Marsaulina ${ }^{3}$ |}

\author{
1,2,3 Department of \\ Environmental Health, \\ Faculty of Public Health, \\ Universitas Sumatera Utara, \\ Indonesia.
}

*irwansyahlubis34@gmail.com

\begin{abstract}
The purpose of this study was to analyze the relationship between basic sanitation facilities and personal hygiene with the incidence of diarrhea in breastfeeding infants in Sinabung post-eruption settlement, Berastagi District, Karo Regency in 2021. This study was a quantitative study with a Cross Sectional Study design. Data analysis using chi-square test with a sample of 100 mothers who have toddlers aged 6-24 months. The results showed that the related variables were basic sanitation facilities $(p=0.014)$ and hand hygiene $(p=0.020)$ with the incidence of diarrhea in breastfeeding infants. Suggestions for this study to health workers are expected to carry out health promotion and education about basic sanitation and personal hygiene to mothers whose toddlers do not experience diarrhea to prevent an increase in cases of diarrhea and to provide treatment and education to mothers whose toddlers experience diarrhea so as not to occurrence of complications or severity of diarrhea to prevent death. KEYWORDS

basic sanitation facilities; personal hygiene; diarrhea
\end{abstract}

\section{INTRODUCTION}

Sanitation is an effort to monitor several aspects of the physical environment that affect living things, including problems that affect damage to physical development and their impact on health and survival. Sanitation is related to environmental health which can affect the degree of public health. This triggers are the poor sanitation, the poor environmental condition, and inadequate availability of clean water. Sanitation has an important role to realize the healthy life and it also is as a pillar to prevent various problems related to the environment.

From the report (WHO 2015) there are 2.4 billion people who use sanitation facilities below health standards. Data from (Ministry of Health of the Republic of Indonesia, 2018) the percentage from households that have access to proper sanitation is $69.27 \%$. Based on these data, it can be assumed that the target of the Ministry of Health's basic sanitation plan has not been achieved, which is $75 \%$. Inadequate environmental conditions are one of aspects to increase the incidence of diarrhea. Where basic sanitation includes aspects of clean water facilities, disposal facilities, garbage disposal and waste disposal facilities related to the incidence of diarrhea (Octorina, 2016).

Mother's personal hygiene also functions in increasing the problem of diarrhea in infants. Mother is the closest person to the baby who takes care of all the baby's needs such as bathing, providing and providing food/drinks. Unhygienic attitudes such as not washing hands before handling children's food, not washing clean cooking and eating utensils, not 
washing hands after defecating and not keeping nails clean when dirty. This can cause the baby to have diarrhea. Wardhani (2010) in the results of the study said that there was a close relationship between maternal personal hygiene and the incidence of diarrhea as disease carriers

Diarrhea is more common in developing countries than in developed countries. This is caused by several aspects, including the lack of adequate drinking water, lack of understanding of sanitation hygiene and poor nutritional status and public health status. It is estimated that 2.5 billion people have inadequate sanitation facilities and 1 billion people do not have access to clean water.

Diarrhea is a situation where a person defecates with a soft or liquid consistency, moreover it can be in the form of water only and the frequency is more than 3 times a day. Diarrhea is a disease characterized by an increase in the frequency of defecation compared to normal (3 times a day) accompanied by a change in the consistency of the stool to be liquid or soft, with or without blood and/or concentrated fluid

Diarrhea is one of the endemic health problems in Indonesia and has the opportunity for Extraordinary Events to occur which are often accompanied by mortality. In 2017 there were $6,897,463$ people and the number of diarrhea sufferers treated by health facilities was $3,198,411$ people $(46.4 \%)$ and in 2018 there were $7,157,483$ people with diarrhea in health facilities with the number of diarrhea sufferers served in health facilities by 4,165,789 people (58.20\%) (Ministry of Health, 2018).

The results of Rizkiyanto's research (2015) regarding the effect of the availability of basic sanitation facilities in flood-prone areas on the incidence of diarrhea indicate that in the working area of the Mangkang Public Health Center, Semarang City. The four variables studied that have the coherence where the physical condition of clean water facilities, latrine facilities, garbage disposal facilities or relationship between basic sanitation in flood-prone areas and the incidence of diarrhea in the work area of Center Mangkang Health Office.

Berastagi district is a district located in Karo Regency, North Sumatra province, where the Sinabung eruption disaster was one of the factors for poor basic sanitation so that the coverage of diarrhea cases in 2018 totaled 1,346 people of all ages. While the number of cases of diarrhea in toddlers is 406 toddlers (Profile of Karo RegencyHealth Office, 2018).

Based on the results of the preliminary survey, of the 30 houses with breastfeeding infants who were observed, 20 respondents $(66.7 \%)$ had poor basic sanitation and personal hygiene, while 10 respondents $(33.3 \%)$ had good basic sanitation and personal hygiene in settlements. After the Sinabung Eruption, Berastagi District, Karo Regency.

The results of a preliminary survey conducted by researchers by interviewing 30 mothers who have breastfeeding infants, it is assumed that from 30 children under five there are 20 children under five $(66.7 \%)$ who experience diarrhea and 10 children under five $(33.3 \%)$ who do not experience diarrhea. in Sinabung Post-Eruption Settlement, Berastagi District, Karo Regency.

\section{RESEARCH METHODS}

\section{Types of Research}

This research is a quantitative research with a cross sectional study design.

\section{Population and Sample}

The population in this study were children under five who lived in the Post-Eruption Sinabung Settlement, Berastagi District, Karo Regency.

The sample size in this study were breastfeeding infants living in post-eruption settlements of Sinabung, Berastagi District, Karo Regency as many as 100 people. 
Inclusion criteria:

1. Mothers who have toddlers aged 6-24 months;

2. Toddler is still breastfeeding;

3. No symptoms of mal absorption;

4. No history of allergies;

5. No poisoning.

Exclusion criteria:

1. Toddlers who are not breastfeeding

2. Secondary data

3. Secondary data was obtained from data on cases of diarrhea in toddlers obtained from Karo Regency Health Office in 2018.

\section{Operational Definition}

1. Diarrhea is a condition in which toddlers at the age of 6-24 months experience loose and liquid bowel movements or can be in the form of water with a frequency that is more frequent than usual (> 3 times a day) in the past month.

2. Personal hygiene is a person's actions in maintaining and improving his health.

3. The habit of hand washing is the act of washing hands with soap with clean water accompanied by running water properly.

4. Nail hygiene is the act of keeping nails clean by cutting nails regularly and cleaning dirty nails with soap when bathing.

5. Activities to maintain the cleanliness of foodstuffs are the conditions of foodstuffs that are protected from damage, while also protecting them from contamination, whether carried by foodstuffs or environmental factors that will enter foodstuffs.

6. Basic sanitation is the condition of fulfilling health requirements which include clean water facilities, provision of latrines, waste water disposal facilities and waste disposal facilities.

7. Clean water is the availability of clean water that meets health requirements, namely tasteless, colorless and odorless

8. Availability of latrines is the availability of privately owned latrines with the type of goose-neck latrine/plesengan, not waterproof, non-slip, water and cleaning equipment available, odorless, and has a septic tank.

9. Waste water disposal facilities are those that meet the requirements, such as those with flowing water and closed channels.

10. Garbage disposal facility is an effort to manage waste that is privately owned, waterproof and disposed of in a closed place.

\section{Dependent Variable}

1. The incidence of diarrhea

Measuring Tool: Questionnaire further categorized into:

1. No ( $<3$ times a day)

2. Yes ( $\geq 3$ times a day)

\section{Independent Variable}

1. Basic sanitation advice:

1. Eligible

2. Not eligible

2. The habit of washing hands with soap

1. OK 


\section{Not Good}

3. Nail hygiene

1. OK

2. Not Good

4. Cleanliness of food material management

1. OK

2. Not Good

\section{Data Analysis Method \\ Univariate Analysis}

All research variables were conducted to obtain an overview of the basic sanitation facilities (clean water facilities, waste disposal facilities/latrines, garbage disposal facilities and waste water disposal facilities), personal hygiene (hand hygiene, nail hygiene and food material management hygiene) and diarrhea. Which is presented in the form of a frequency distribution table.

\section{Bivariate Analysis}

Bivariate analysis is useful to see the relationship between the independent variables (basic sanitation facilities, hand hygiene, nail hygiene and food hygiene management) and the dependent variable (diarrhea incidence). The type of data is categorical, so the analysis technique used is chi square. If the $p$ value $<0.05$, it means that there is a significant relationship between the two variables.

\section{RESULTS AND DISCUSSION}

\section{Univariate Analysis Results}

Distribution of the frequency of basic sanitation facilities, personal hygiene (hand hygiene, nail hygiene and food preparation hygiene) and the incidence of diarrhea in breastfeeding toddlers in the Post-Eruption Sinabung Settlement, Berastagi District, Karo Regency in 2021.

\begin{tabular}{lcc}
\hline Variabel & N=100 & Percentage (\%) \\
\hline Basic Sanitation Facilities & & \\
$\quad$ Qualify & 49 & 49 \\
$\quad$ Not eligible & 51 & 51 \\
\hline Hand Hygiene & 31 & 31 \\
Well & 69 & 69 \\
$\quad$ Not good & & \\
Nail Hygiene & 38 & 38 \\
Well & 62 & 62 \\
$\quad$ Not good & & \\
Food Hygiene & 37 & 37 \\
Well & 63 & 63 \\
$\quad$ Not good & & \\
\hline Diarrhea & 35 & 35 \\
Not & 65 & 65 \\
Yes & & \\
\hline
\end{tabular}

In the variable basic sanitation facilities, 49 respondents (49\%) had basic sanitation facilities that met the requirements, while 51 respondents $(51 \%)$ whose basic sanitation facilities did not meet the requirements. Based on the hand hygiene variable, it is known that the good category is 31 respondents (31\%), while the poor category is 69 respondents $(69 \%)$. Based on the nail hygiene variable, it is known that the good category is 38 respondents 
(38\%), while the poor category is 62 respondents $(6 \%)$. Based on the food hygiene variable, it is known that the good category is 37 respondents (37\%), while the poor category is 63 respondents $(63 \%)$. Based on the category of diarrhea incidence in breastfeeding infants, there were 35 respondents $(35 \%)$ with the category of having diarrhea and the category of not having diarrhea as many as 65 respondents (65\%).

\section{Bivariate Analysis Results}

The relationship between basic sanitation facilities and personal hygiene (hand hygiene, nail hygiene and food hygiene with the incidence of diarrhea in breastfeeding toddlers in settlements after Sinabung eruption, Berastagi District, Karo Regency in 2021.

\begin{tabular}{|c|c|c|c|c|c|c|c|c|}
\hline \multirow{3}{*}{ Variable } & \multicolumn{6}{|c|}{ Diarrhea } & \multirow{3}{*}{$\begin{array}{l}\text { p. } \\
\text { value }\end{array}$} & \multirow{3}{*}{$\begin{array}{l}\mathbf{R P} \\
(95 \% \mathrm{CI})\end{array}$} \\
\hline & \multicolumn{2}{|c|}{ No } & \multicolumn{2}{|c|}{ Yes } & \multicolumn{2}{|c|}{ Total } & & \\
\hline & $\mathrm{n}$ & $\%$ & $\mathrm{n}$ & $\%$ & $\mathrm{n}$ & $\%$ & & \\
\hline \multicolumn{9}{|c|}{ Basic Sanitation Facilities } \\
\hline Qualify & 23 & 46,9 & 26 & 53,1 & 49 & 100 & \multirow[b]{2}{*}{0,014} & \multirow{2}{*}{$\begin{array}{l}2,875 \\
(1,221-6,770)\end{array}$} \\
\hline Not eligible & 12 & 23,5 & 39 & 76,5 & 51 & 100 & & \\
\hline \multicolumn{9}{|l|}{ Hand Hygiene } \\
\hline Well & 16 & 51,6 & 15 & 48,4 & 31 & 100 & \multirow{2}{*}{0,020} & \multirow{2}{*}{$\begin{array}{l}2,807 \\
(1,164-6,771)\end{array}$} \\
\hline Not good & 19 & 27,5 & 50 & 72,5 & 69 & 100 & & \\
\hline \multicolumn{9}{|l|}{ Nail Hygiene } \\
\hline Well & 16 & 42,1 & 22 & 57,9 & 38 & 100 & \multirow{2}{*}{0.244} & \multirow{2}{*}{$\begin{array}{l}1,646 \\
(0,710-3,814)\end{array}$} \\
\hline Not good & 19 & 30,6 & 43 & 69,4 & 62 & 100 & & \\
\hline \multicolumn{9}{|l|}{ Food Hygiene } \\
\hline Well & 11 & 29,7 & 26 & 70,3 & 37 & 100 & \multirow{2}{*}{0,397} & \multirow{2}{*}{$\begin{array}{l}0.688 \\
(0,288-1,640)\end{array}$} \\
\hline Not good & 24 & 38,1 & 39 & 61,9 & 63 & 100 & & \\
\hline
\end{tabular}

The results of the chi-square test showed that of the 4 independent variables, there were 2 (two) variables that were significantly related to the incidence of diarrhea, namely basic sanitation facilities and hand hygiene. This is indicated by the sig-p values of the two variables, which are 0.014 and 0.020 , whose p-value is less than 0.05 .

\section{Discussion}

\section{Relationship of Basic Sanitation Facilities with Diarrhea}

The results of the descriptive analysis prove that the majority of the samples have basic sanitation facilities that do not meet the requirements, namely 51 respondents (51\%) and basic sanitation facilities meet the requirements as many as 49 respondents (49\%). The results of statistical analysis using the chi-square test obtained a value of $p=0.014(p<0.05)$ so that statistically it can be interpreted that there is a relationship between basic sanitation facilities and the incidence of diarrhea in breastfeeding infants in the post-eruption settlements of Sinabung, Berastagi District, Karo Regency. The odd ratio value is 2.875 which is between 1.221 until 6.770 which means that if the basic sanitation facilities meet the requirements, the probability of not experiencing diarrhea is 2.875 times. This can happen because of the 51 respondents whose basic sanitation facilities were not good, 12 respondents $(23.5 \%)$ did not experience diarrhea and 39 respondents $(76.5 \%)$ experienced diarrhea.

The results of this study are in line with the research of Irfan and Delima (2018), there is a significant relationship between the facilities condition: clean water supply, family latrines, waste water disposal and family garbage disposal with the incidence of diarrhea in children under five in Limau Manis Selatan Village, the Pauh Health Center working area.

The condition of clean water facilities is closely related to the pollution that can occur in clean water. Therefore, to prevent contamination of clean water, water facilities. To prevent 
diarrhea, clean water must be taken from sources that are safe and protected/not contaminated, that is, it must be far from cattle pens, latrines at least 10 meters from water sources and meet the physical criteria for water no (cloudy, tasteless, smelly and colored). Clean water facilities can be a medium for transmitting various diseases carried by water if the facilities are not sanitary. Clean water facilities in addition to quantity, quality must meet applicable standards, uThe results of this study are in line with the research of Irfan and Delima (2018), there is a significant relationship between the condition of the facilities: clean water supply, family latrines, waste water disposal and family garbage disposal with the incidence of diarrhea in children under five in Limau Manis Selatan Village, the Pauh Health Center working area.

The condition of clean water facilities is closely related to the pollution that can occur in clean water. Therefore, to prevent contamination of clean water, water facilities. To prevent diarrhea, clean water must be taken from sources that are safe and protected/not contaminated, that is, it must be far from cattle pens, latrines at least 10 meters from water sources and meet the physical criteria for water no (cloudy, tasteless, smelly and colored). Clean water facilities can be a medium for transmitting various diseases carried by water if the facilities are not sanitary. Clean water facilities in addition to quantity, quality must meet applicable standards, to prevent the occurrence and spread of water-borne diseases. However, clean water is often stored in water that is not clean or easily contaminated, so water that has been safe or healthy will become dangerous again. Thus, to prevent contamination of water, the water must be thoroughly cooked before drinking. Toddlers suffering from diarrhea are more common in respondents who do not use latrines or latrines that do not meet health requirements. The problem of human waste disposal is a major problem, so it needs to be addressed as early as possible because human waste is the source of the spread of disease. The spread of diseases originating in human waste can be through various ways such as through water, hands, insects and soil. Efforts to improve environmental sanitation through the use of latrines that meet health requirements can reduce the incidence of diarrhea. Inadequate wastewater treatment can have a negative impact on public health and on the environment, among others, being a transmission or media for the spread of various diseases, especially diarrhea. Causes unpleasant odors and is a source of water pollution. Disposal of waste water that is carried out in an unhealthy manner or does not meet health requirements can cause contamination of the soil surface and water sources. Thus, to prevent or reduce contamination of wastewater to the environment, waste must be managed properly, so that wastewater does not become a breeding ground for disease germs such as flies, does not pollute water sources, soil and does not cause odors. Efforts that can be made to prevent the transmission of diarrhea is better to make a closed SPAL and always maintain the sanitation of the waste water disposal (SPAL) so that there is no puddle of water and becomes a medium for the transmission of diarrheal diseases. Garbage is also a basic sanitation that can affect the incidence of diarrhea. Garbage is all substances or objects that are not used either from households or the result of industrial processes which are usually organic and inorganic types. Garbage needs to be managed properly so as not to pollute the environment either from its aroma or from its leachate which can contaminate ground water and surface water. In addition, the presence of garbage left in the open becomes a breeding ground for disease vectors such as flies which can later carry bacteria when the flies land on food. However, clean water is often stored in water that is not clean or easily contaminated, so water that has been safe or healthy will become dangerous again. Thus, to prevent contamination of water, the water must be thoroughly cooked before drinking. Toddlers suffering from diarrhea are more common in respondents who do not use latrines or latrines that do not meet health requirements. 


\section{Relationship between Hand Hygiene and Diarrhea}

The results of the descriptive analysis prove that the majority of the samples who are not good at hand hygiene are 69 respondents (69\%) and the good ones are 31 respondents (31\%). The results of statistical analysis using the chi-square test obtained $p$ value $=0.020(p<0.05)$ so that statistically it can be interpreted that there is a relationship between hand hygiene and the incidence of diarrhea in breastfeeding toddlers in post-eruption settlements of Sinabung, Berastagi District, Karo Regency. The odd ratio value is 2.807 which is between 1.164 until 6.771 which means that if the hand hygiene is good, the probability of experiencing no diarrhea is 2.807 times. Of the 69 respondents in the unfavorable category, 19 respondents (27.5\%) did not experience diarrhea and 50 respondents $(72.5 \%)$ experienced diarrhea.

The results of this study are in line with the results of Rukmini's research (2016) which revealed that there was a significant relationship between the relationship between hand washing habits and diarrhea in Early Childhood Education Programs, Tambak Wedi Village, Kenjeran District, Surabaya. Hand hygiene is the most influential variable or dominant factor in this study. Hand hygiene is the main factor that influences breastfeeding toddlers to experience diarrhea. This happens because hand hygiene also determines the health of children. Clean hands is one of the efforts to prevent disease transmission, diseases that are transmitted through hands include diarrhea. The habit of washing hands is closely related to the incidence of diarrhea. In addition, maintaining hand hygiene is also related to how to wash hands properly and correctly, namely washing hands with soap and running water as often as possible or at least when eating. Toddlers who have the awareness to wash their hands before eating are still relatively small because their daily parenting patterns are still accompanied by their parents. This results in many diseases, especially diarrhea.

According to Hamzah (2020), the habit of washing hands with clean water and soap is associated with the incidence of diarrhea in toddlers. Hand washing is a positive behavioral action taken to kill germs on hands. It is proven that by doing the act of washing hands with soap is one of the preventive activities by humans to be clean and break the chain of diseasecausing microorganisms that exist in the fingers. In dense and slum residential environments, the habit of washing hands with soap properly and correctly can reduce half (50\%) of people with diarrhea (Fatmawati and Indrawati, 2017).

Another study also explained that there was a significant relationship between maternal personal hygiene, hand and nail hygiene of toddlers, food/drink handling and the risk of contamination of dug wells with the incidence of diarrhea in toddlers in the Pauh Public Health Center in Padang City in 2015 (Rahmi, 2015).

\section{Relationship between Nail Hygiene and Diarrhea}

The results of the descriptive analysis proved that the majority of the samples had poor nail hygiene as many as 62 respondents (62\%) and 38 respondents $(38 \%)$. The results of statistical analysis using the chi-square test obtained $\mathrm{p}$ value $=0.244(\mathrm{p}>0.05)$ so that statistically it can be interpreted that there is no relationship between nail hygiene and the incidence of diarrhea in breastfeeding infants in the post-eruption settlement of Sinabung, Berastagi District, Karo Regency. The odd ratio value is 1.646 which is between 0.710-3.814 which means that if the nail hygiene is good, the probability of having diarrhea is 1.646 times. From 62 respondents with poor nail hygiene category, 19 respondents $(30.6 \%)$ did not experience diarrhea and 43 respondents (69.4\%) experienced diarrhea.

Keeping nails clean is one of the important aspects in maintaining one's personal hygiene because various germs can enter the body through nails. Therefore, nails should be kept in a healthy and clean condition and nail care can also affect nail growth. The habit of biting nails is a habit that is always done by children, either after playing or holding something. In 
addition to being unhealthy for nail health because nails can cause them to become damaged or swollen, nails can become a breeding ground for germs if they are not cleaned regularly. The habit of biting nails can cause germs to enter the body through the mouth and into the digestive tract. This will be the entrance for germs that cause diarrhea and other digestive diseases. One way to prevent diarrhea is to keep your body clean by keeping your nails short and cleaning them regularly. There is a relationship between nail hygiene and the incidence of diarrhea in children aged 4-5 years in Muntoi Timur Village in Passi Barat District, Bolaang Mongondow Regency (Hamzah, 2020).

\section{Relationship between Food Hygiene and Diarrhea}

The results of the descriptive analysis prove that the majority of the samples are not good in terms of food hygiene as many as 63 respondents (63\%) and 37 respondents (37\%). The results of statistical analysis using the chi-square test obtained $\mathrm{p}$ value $=0.397(\mathrm{p}>0.05)$ so that statistically it can be interpreted that there is no relationship between food hygiene and the incidence of diarrhea in breastfeeding infants in post-eruption settlements of Sinabung, Berastagi District, Karo Regency. The odd ratio value is 0.688 which is between 0.288 1.640 , which means that if the food hygiene is good, the probability of not experiencing diarrhea is 0.688 times. Of the 63 respondents in the category of poor nail hygiene, 24 respondents $(38.1 \%)$ did not experience diarrhea and 39 respondents $(61.9 \%)$ experienced diarrhea.

Healthy food is food that contains nutrients. However, healthy food is not only the type but the way of presentation and how to consume it must be healthy as well. A healthy way of serving must be in tightly closed packaging that is free from flies, mosquitoes. How to consume the right way to keep these foods healthy is to always pay attention to hand hygiene through washing hands before eating. Good food must include six principles of hygiene, namely the condition of food ingredients must be in good condition / not rotten, how to store food ingredients must be in the right place, food processing methods must be correct, transportation methods must be free from dirt or insects, food storage methods must be in a closed, clean place and the way of serving it must pay attention to food hygiene and hand hygiene before consuming it. Many children, including toddlers, like to consume food regardless of food hygiene, such as food in packages that are not tightly closed, infested with flies (Rukmini, 2016).

In terms of ensuring the cleanliness of foodstuffs, mothers have an important role because they are the ones who take care of the children every day. Of course, mothers must know how to ensure the cleanliness and health of food ingredients for their families, especially their toddlers.

\section{CONCLUSION}

1. Basic sanitation facilities have a significant relationship with the incidence of diarrhea in breastfeeding infants in post-eruption settlements of Sinabung, Berastagi District, Karo Regency in 2021. This is indicated by the sig-p value (basic sanitation facilities) $=0.014<0.05$.

2. Hand hygiene has a significant relationship with the incidence of diarrhea in breastfeeding infants in the post-eruption settlements of Sinabung, Berastagi District, Karo Regency in 2021. This is indicated by the sig-p value (hand hygiene) $=0.020<$ 0.05 .

3. Nail hygiene does not have a significant relationship and influence with the incidence of diarrhea in breastfeeding infants in the post-eruption settlements of Sinabung, 
Berastagi District, Karo Regency in 2021. This is indicated by the sig-p value (nail hygiene) $=0.244<0.05$.

4. Food hygiene does not have a significant relationship and influence with the incidence of diarrhea in breastfeeding infants in the post-eruption settlements of Sinabung, Berastagi District, Karo Regency in 2021. This is indicated by the sig-p value (cleanliness of foodstuffs) $=0.397<0.05$.

\section{REFERENCES}

Achmadi, U.F. (2011). Manajemen Penyakit Berbasis Wilayah. Jakarta: Universitas Indonesia.

Chandra Dya. (2007). Hubungan Antara Kepemilikan Jamban dengan Kejadian Diare di Desa Karangagung Kecamatan Palang Kabupaten Tuban. Fakultas Kesehatan Masyarakat Universitas Airlangga.

Dinas Kesehatan Kabupaten Karo. (2018). Profil Kesehatan Tahun 2018. Karo

Fatmawati, T. Y. and Indrawati, I. (2017). Analisis Penggunaan Air Bersih, Mencuci Tangan, Membuang Tinja Dengan Kejadian Diare pada Balita, Jurnal Endurance, 2(3), pp. 294-302.

Fiesta Octorina, Surya D. and Irnawati M. (2012). Hubungan Kondisi Lingkungan Perumahan dengan Kejadian Diare di Desa Sialang Buah Kecamatan Teluk Mengkudu Kabupaten Serdang Bedagai Tahun 2012 . Jurnal.usu.ac.id/index.php/ikk/arrticle/download/3282/1609.

Irfan, Asep., \& Delima. (2018). Sarana Sanitasi Dasar dengan Kejadian Diare pada Balita. Jurnal Sehat Mandiri, 13(2).

Kementerian Kesehatan RI. (2017). Profil Kesehatan Indonesia Tahun 2017. . (2018). Profil Kesehatan IndonesiaTahun 2018.

Octorina Fiestam, et al. (2012). Hubungan Kondisi Lingkungan Perumahan dengan Kejadian Diare di Desa Sialang Kecamatan Teluk Mengkudu Kabupaten Serdang Begadai Tahun 2012. Fakultas Kesehatan Masyarakat Universitas Sumatera Utara.

Rahmi, Firmansyah. (2015). Faktor-Faktor yang Berhubungan dengan Kejadian Diare Pada Balita Di Wilayah Kerja Puskesmas Pauh Kota Padang Tahun 2015.

Rizkiyanto, M. (2015). Pengaruh Ketersediaan Sarana Sanitasi Dasar dan Status Rawan Banjir Terhadap Kejadian Diare.

Rukmini. (2016). Hubungan Makanan dan Kebiasaan Cuci Tangan dengan Kejadian Kejadian Diare Pada Anak Usia Dini Di Kelurahan Tambak Wedi Kecamatan Kenjaren Surabaya. Adi Husada Nursing Journal, 2(1).

World Health Organization. (2000). Bahaya Bahan Kimia pada Kesehatan Manusia dan Lingkungan (Terjemahan Palupi Widyastuti), Jakarta : EGC 